\title{
The impact analysis of rice field conversion on food security in Sragen Regency
}

\author{
Desta Prasanthi Anggraini ${ }^{*}$,Joko Sutrisno, and Umi Barokah \\ Agribusiness Study Program, Agriculture Department, 57126 Universitas Sebelas Maret, Surakarta, \\ Indonesia
}

\begin{abstract}
Sragen Regency is one of the food barn areas in Central Java Province. Along with the population growth and development activities, the need for land is increased. Meanwhile, the availability of land remains still. This gap can lead to rice field conversion. In the long term, rice field conversion can affect food security. Therefore, the research was conducted to (1) determine rice field conversion's rate, (2) affecting factors, (3) its impact on food security in Sragen Regency. The results showed that the rice field conversion's rate in Sragen Regency fluctuated by an average of $0.13 \%$ per year. The results of multiple linear regression showed that the amount of Gross Regional Domestic Product, total population, the number of industries, building and yard area, and the number of schools simultaneously affect the rice field conversion. Furthermore, the amount of Gross Regional Domestic Product, total population, and number of schools also affect partially. The impact of the rice field conversion was the loss of rice production by $6,147.40$ tons. However, according to surplus-deficit analysis, food security in Sragen Regency is a surplus, which means that it is resistant even though there is rice field conversion.
\end{abstract}

\section{Introduction}

The importance of land to fulfill human needs is increasing, while the availability of land remains (does not increase). The increase in land demand triggers land conversion [1]. Land conversion is an activity of changing the function of part or all of the land area from its original function to another function [2]. Agricultural land is the most widely used land for land conversion activities. This can happen because the land area in the agricultural sector is relatively more extensive than the other sectors, so that agricultural land is considered very potential for land conversion for the non-agricultural sector [3].

Land conversion occurs along with the development of the area. The area's development can be seen by emphasizing economic growth by looking at the sector's contribution to Gross Domestic Product (GDP). Land use is prioritized for a sector with the biggest contribution to GDP [4]. The agricultural, forestry and fisheries sectors rank after the industrial and trade sectors [4]. This can encourage agricultural land conversion to other sectors. Another factor that encourages land conversion is the increase in the population [5]. Population growth can increase land needs, such as settlements, industrial development,

*Corresponding author: destaprasanthia@gmail.com 
and educational facilities. On the other hand, the increase in population means that food needs are increasing [6].

Sragen Regency is one of the food barns of Central Java Province by being the number two rice producer in Central Java in 2019. Data on rice production are in Table 1. However, in Sragen Regency, there is still a rice field conversion. Sragen Regency has lost 396.52 hectares of lowland agricultural land in 10 years [4].

Table 1. Five Regencies in Central Java, Highest Rice Production by 2019.

\begin{tabular}{|c|l|c|}
\hline No. & \multicolumn{1}{|c|}{ Regencies } & Paddy Production (Ton) \\
\hline 1. & Grobogan Regency & $772,521.47$ \\
\hline 2. & Sragen Regency & $\mathbf{7 6 6 , 0 1 2 . 3 0}$ \\
\hline 3. & Cilacap Regency & $699,964.69$ \\
\hline 4. & Demak Regency & $666,141.30$ \\
\hline 5. & Pati Regency & $592,099.74$ \\
\hline
\end{tabular}

The decrease of rice field can be followed by a decrease in rice production. This condition is hypothesized will also affect the land area and agricultural productivity. Furthermore, it will affect the food, and in the long term, it can be a threat to food security in Sragen Regency. The impact of the rice field conversion on food security can be measured by calculating the food surplus deficit. In addition, this research also calculates the rice field conversion's rate in Sragen Regency and the factors that affect it. The affecting factors were calculated using multiple regression analysis. The variables are GRDP (Gross Regional Domestic Product), population, number of industries, building and yard area, and number of schools.

\section{Research methods}

Determining the location of the research was done purposively in Sragen Regency, Central Java, Indonesia. The type of data used in this research is secondary data. The data are rice field area, rice field productivity, the amount of GRDP in Sragen Regency, populations, the number of industries, the area of buildings and yards, and the number of schools. The secondary data used are from the Central Bureau of Statistics (BPS) of Sragen Regency, National Land Office (BPN), Regional Development Planning Agency (Bappeda), Industry and Trade Departement, Food Security, and Agriculture Departement. Data analysis of this research analyzes the rate of rice field conversion using the formula of:

$$
V=\left(L t-L t_{-1}\right):\left(L t_{-1}\right) \times 100 \%
$$

where

$\mathrm{V} \quad$ : rice field conversion's rate (\%)

$\mathrm{Lt}$ : rice field area in year $\mathrm{t}(\mathrm{Ha})$

$\mathrm{Lt}_{-1}$ : rice field area in the year before $\mathrm{t}(\mathrm{Ha})$.

For the factors that affect rice field conversion, the analysis used is multiple linear regression. Systematically the models used are:

$$
Y=a+b 1 X 1+b 2 X 2+b 3 X 3+b 4 X 4+b 5 X 5+e
$$

where

$\mathrm{Y} \quad$ : rice field conversion

a : constant 
X1 : GRDP (Gross Regional Domestic Product)

$\mathrm{X} 2$ : population

$\mathrm{X} 3$ : number of industries

$\mathrm{X} 4$ : building and yard area

X5 : number of schools.

e : error

And for the food security analyzed using food surplus or deficit method, the difference between food availability and demand [2].

Surplus/deficit $=$ food availability - food demand

\section{Result and discussion}

\subsection{Rice field conversion's rate in Sragen Regency in 2000-2009}

Table 2. Rice field conversion's rate in Sragen Regency in 2000-2019.

\begin{tabular}{|c|c|c|c|}
\hline Year & Rice field area $\mathbf{H a})$ & $\begin{array}{c}\text { Rice field conversion area } \\
\mathbf{( H a )}\end{array}$ & $\begin{array}{c}\text { Rice field } \\
\text { conversion's rate } \\
\mathbf{( \% )}\end{array}$ \\
\hline 2000 & $40,133.93$ & - & 0.000 \\
\hline 2001 & $40,039.29$ & 94.64 & 0.236 \\
\hline 2002 & $40,037.93$ & 1.36 & 0.003 \\
\hline 2003 & $40,037.93$ & 0.00 & 0.000 \\
\hline 2004 & $40,037.93$ & 0.00 & 0.000 \\
\hline 2005 & $39,759.00$ & 278.93 & 0.702 \\
\hline 2006 & $39,759.00$ & 0.00 & 0.000 \\
\hline 2007 & $40,339.00$ & 0.00 & 0.000 \\
\hline 2008 & $40,339.00$ & 0.00 & 0.000 \\
\hline 2009 & $40,127.45$ & 211.55 & 0.527 \\
\hline 2010 & $40,127.45$ & 0.00 & 0.000 \\
\hline 2011 & $40,127.45$ & 0.00 & 0.000 \\
\hline 2012 & $40,182.00$ & 0.00 & 0.000 \\
\hline 2013 & $40,182.00$ & 0.00 & 0.000 \\
\hline 2014 & $40,121.00$ & 61.00 & 0.152 \\
\hline 2015 & $39,835.00$ & 286.00 & 0.718 \\
\hline 2016 & $39,799.40$ & 35.60 & 0.089 \\
\hline 2017 & $39,768.96$ & 30.44 & 0.077 \\
\hline 2018 & $39,748.92$ & 20.04 & 0.050 \\
\hline 2019 & $39,730.93$ & 17.99 & 0.045 \\
\hline Total & & $1,037.55$ & 2.600 \\
\hline & Mean & 51.88 & 0.13 \\
\hline
\end{tabular}

Based on table 2, the total amount decreasing rice field area in Sragen Regency is 2.6 percent or $-1,037.55$ hectares with an average rice field conversion is 51.88 hectares, and average conversion rate is $0.13 \%$ per year. In 2005 and 2009, there was a land acquisition for the first and second phases of toll road construction in Sragen Regency. In 2015 there was a program from the Government, which is subsidized housing, namely the construction of housing for Low-Income Communities, the construction of a double-track train and exit toll gates (outside the toll road) in the subdistrict of Sambungmacan and Gondang, as well as the construction of a rest area located in Masaran subdistrict. This land conversion is 
called systematic. Systematic land conversion generally covers a relatively large and consolidated expanse [7].

\subsection{Factor's affecting land conversion}

Table 3 Factor's affecting land conversion.

\begin{tabular}{|l|c|c|c|}
\hline & $\begin{array}{c}\text { Unstandardized } \\
\text { Coefficients }\end{array}$ & \multirow{2}{*}{ T } & \multirow{2}{*}{ Sig. } \\
\cline { 2 - 2 } & B & 2.520 & 0.025 \\
\hline (Constant) & 28.63042 & 2.884 & 0.012 \\
\hline Total GRDP & $20.788^{* *}$ & -2.175 & 0.047 \\
\hline Total Population & $-190.566^{* *}$ & 0.087 & 0.932 \\
\hline Industry unit & $1.594^{\mathrm{ns}}$ & -0.568 & 0.579 \\
\hline $\begin{array}{l}\text { Buildings and yards } \\
\text { area }\end{array}$ & $-16.945^{\mathrm{ns}}$ & -1.880 & 0.081 \\
\hline Number of school & $-61.759^{*}$ & & \\
\hline
\end{tabular}

ns : not significant

* : significant less than $\alpha=10 \%$

** : significant less than $\alpha=5 \%$

Based on Table 3, the results of the partial test (t-test) of variables that have a significance or less than $\alpha=5 \%(0.05)$ are the amount of GRDP (X1) and total population (X2). The variable with a significance value less than $=10 \%(0.1)$ is the number of schools (X5). For others variables are not significant.

The amount of GRDP significantly affects rice field area with a significance level of 0.012 which is smaller than $\alpha=5 \%(0.05)$. The value of the X1 coefficient (total GRDP) is 20.788. This shows that for each additional unit of GRDP, in this case, 1 million rupiah, it will increase the rice field area by 20.788 hectares. The amount of GRDP in Sragen Regency, which increases every year, can be an indicator of economic growth. Economic growth will encourage the construction of public facilities as well as infrastructure. GRDP affects on increasing the rice field area [8]. This is possible because the agricultural sector is still the most prominent sector supporting the economy of the Sragen Regency. The agricultural sector is the dominant sector, so the development of the agricultural sector in Sragen Regency still needs to be optimized to improve the population's welfare.

Based on the t-test results, the population has a significant effect on the rice field area with a significance level of 0.047 which is smaller than $\alpha=5 \%(0.05)$. The value of the X2 coefficient is -190.566 . The population variable has a negative effect. This shows that each additional population of one unit, in this case 1 person, will reduce the area of rice field by 190.566 hectares. The number of people who increase every year is inversely proportional to the availability of land, which makes population have a significant effect on the reduction in rice field area [9]. The consequence of the increasing population is the need for economic development and social services. Some aspects that need improvement following the increase in population are health services, education, and infrastructures such as roads, supermarkets, or shops. The development of these services, of course, requires land. The limited amount of land becomes an obstacle in overcoming these problems, which lead to the rice fields conversion. Population growth accelerates land conversion and reduces the potential for food production per capita [10].

For the number of schools has a significant effect on the rice field conversion with a significance level of 0.081 , which is smaller than $\alpha=10 \%(0.1)$. X5 coefficient value is minus 61.759. This shows that each additional school unit by one unit, in this case, 1 unit, will reduce rice field area by 61,759 hectares. The number of schools in Sragen Regency 
has increased every year along with the increase in population. For example, in 2015, there was a rice field conversion to construct of a Vocational School (SMK) in Tanon Subdistrict.

\subsection{Rice Production Loss (ton)}

Tabel 4. Rice Production Loss (ton)

\begin{tabular}{|c|c|c|c|}
\hline Year & Productivity (ton/ha) & Rice field area (ha) & Rice production loss (ton) \\
\hline 2000 & 5.29 & & - \\
\hline 2001 & 5.19 & 94.64 & 491.03 \\
\hline 2002 & 5.47 & 1.36 & 7.44 \\
\hline 2003 & 5.53 & 0.00 & 0.00 \\
\hline 2004 & 5.33 & 0.00 & 0.00 \\
\hline 2005 & 5.43 & 278.93 & $1,514.31$ \\
\hline 2006 & 5.40 & 0.00 & 0.00 \\
\hline 2007 & 5.42 & 0.00 & 0.00 \\
\hline 2008 & 5.72 & 0.00 & 0.00 \\
\hline 2009 & 5.86 & 211.55 & $1,238.66$ \\
\hline 2010 & 5.75 & 0.00 & 0.00 \\
\hline 2011 & 5.94 & 0.00 & 0.00 \\
\hline 2012 & 6.11 & 0.00 & 0.00 \\
\hline 2013 & 6.06 & 0.00 & 0.00 \\
\hline 2014 & 5.89 & 61.00 & 359.47 \\
\hline 2015 & 6.51 & 286.00 & $1,861.29$ \\
\hline 2016 & 6.48 & 35.60 & 230.72 \\
\hline 2017 & 6.37 & 30.44 & 193.81 \\
\hline 2018 & 6.34 & 20.04 & 127.14 \\
\hline 2019 & 6.87 & 17.99 & 123.52 \\
\hline Total & - & $1,037.55$ & $6,147.40$ \\
\hline Mean & 5.85 & 51.88 & 307.37 \\
\hline
\end{tabular}

Based on the data, there is an area of $1,037.55$ hectares of lost rice fields. The extent of converted rice fields and the high productivity of rice that year affected the amount of rice production loss. Based on Table 4, it can be seen that the greater the rice field conversion every year, the greater the value of lost rice production. Rice production was lost due to the rice field conversion in 2000-2019 with a total 6,147.40 tons, an average of 307.37 tons per year.

\subsection{Food Security in Sragen Regency 2000-2019}

Based on Table 5, it is known that Sragen Regency from 2000 to 2019 has food security that is resistant or surplus. The surplus with an average of 36,565.66 tons. This shows that rice production in Sragen Regency can still be maintained despite rice field conversion. Rice production can still meet the food demand. The level of food security is getting more significant from year to year even though there is a loss of rice field area due to the rice conversion that occurs. 
Table 5. Food Security in Sragen Regency 2000-2019.

\begin{tabular}{|c|c|c|c|}
\hline Year & Rice Availability (Ton) & $\begin{array}{c}\text { Rice Demand } \\
\text { (Ton/year) }\end{array}$ & Difference (Ton) \\
\hline 2000 & $121,881.79$ & $99,569.75$ & $22,312.04$ \\
\hline 2001 & $119,181.81$ & $94,780.63$ & $24,401.18$ \\
\hline 2002 & $125,703.83$ & $95,019.63$ & $30,684.20$ \\
\hline 2003 & $127,072.18$ & $95,428.13$ & $31,644.06$ \\
\hline 2004 & $122,514.65$ & $95,428.13$ & $27,086.52$ \\
\hline 2005 & $123,834.43$ & $95,765.32$ & $28,069.11$ \\
\hline 2006 & $123,241.28$ & $96,395.52$ & $26,845.76$ \\
\hline 2007 & $125,317.89$ & $96,803.68$ & $28,514.21$ \\
\hline 2008 & $132,486.30$ & $97,292.29$ & $35,194.01$ \\
\hline 2009 & $134,793.00$ & $97,900.52$ & $36,892.49$ \\
\hline 2010 & $132,372.12$ & $98,576.91$ & $33,795.21$ \\
\hline 2011 & $136,654.07$ & $99,051.24$ & $37,602.83$ \\
\hline 2012 & $140,758.77$ & $99,510.61$ & $41,248.16$ \\
\hline 2013 & $139,629.20$ & $99,998.11$ & $39,631.09$ \\
\hline 2014 & $135,642.35$ & $97,701.12$ & $37,941.23$ \\
\hline 2015 & $148,730.31$ & $98,081.83$ & $50,648.48$ \\
\hline 2016 & $147,981.26$ & $98,423.60$ & $49,557.65$ \\
\hline 2017 & $145,266.75$ & $98,761.91$ & $46,504.83$ \\
\hline 2018 & $144,672.99$ & $99,070.65$ & $45,602.33$ \\
\hline 2019 & $156,501.91$ & $99,364.00$ & $57,137.92$ \\
\hline Mean & $134,211.84$ & $97,646.18$ & $36,565.66$ \\
\hline
\end{tabular}

The results can occur due to the increase in productivity. It can be seen in Table 4, the productivity rate increases from year to year. This can happen because of the good agricultural intensification program in Sragen Regency. Increased productivity is carried out by using certified superior seeds, and organic fertilizers, and optimizing the use of plant cultivation tools and machines that have been formed at the Agriculture Service in Sragen. Currently, the rice field area in Sragen Regency is larger than the non-agricultural area. So, food demand is fulfilled from within Sragen Regency self-production.

The trend of rice field conversion that occurs in Sragen Regency in the long term can lead decreasing in food security. The relations between the reduction of rice field in Sragen Regency and the decrease in rice production is not only affected to Sragen Regency but also reduces the amount of rice that can be exported to other areas in Central Java Province. In the long term, Sragen Regency, which is the food barn of Central Java Province, should be able to export to outside the region. For the needs of the Sragen people, there will be a food deficit in the future if land conversion activities are not controlled.

Based on the analysis results, it is known that due to land conversion, Sragen Regency loses an average of 307.37 tons of rice production per year. This can increase if the rice field conversion continues. In fact, this can be used for food consumption by Sragen people or export outside the Sragen area. Therefore, rice fields need to be adequately protected by using clear laws and regulations, and there is a need for supervision in the field. A clear and transparent licensing mechanism is needed by involving all stakeholders in the process of land conversion.

Authors would like to thank Departement of Agribusiness, Agriculture Faculty Universitas Sebelas Maret for their support on this research, also for the Central Bureau of Statistics Sragen and the National Land Office Sragen for providing data of this research. 


\section{References}

1. I.M.Y. Prasada, T.A. Rosa. Agricultural Socio-Economic J 14: 210-224 (2018)

2. D. Guan, H. Li, T. Inohae, W. Su, T. Nagaie, K. Hokao. Ecological Modelling 222: 3761-3772 (2011)

3. M. Rondhi, P. A. Pratiwi, V. T. Handini. Land J 7: 148 (2018)

4. Central Bureau of Statistics. Sragen Regency in Figures. pp 183-185 (2020)

5. R. F. Putri, M. Naufal, M. Nandini, D. S. Dwiputra, S. Wibirama, J. T. S. Sumantyo. IOP Conf. Series: Earth and Environmental Science 256 (2019)

6. R. B. Prihatin. Land conversion in city: case study Bandung and Yogyakarta City. Aspirasi 6: 105- 118 (2015)

7. Zainab, A. Suman. The socio-economic impact of the agricultural land conversion to farming communities. Scientific Journal of Students Economics and Business 9: 1-17 (2017)

8. R. Harini, H. S. Yunus, Kasto, S. Hartono. Indonesian J of Georaphy 44: 120 - 133 (2012)

9. Nurliani, I. Rosada. Agriculture and Agricultural Science Procedia 9: 40-46 (2016)

10. C. A. Francis, E. H. Twyla, A. F. Allison, J. H. Paula, E. N. Hana, E.L. Andrea, E. Alexandra. Farmland conversion to non-agricultural uses in the US and Canada: current impacts and concerns for the future. International Journal of Agricultural Sustainability 10: 8-24 (2012) 